\title{
The Affective Moral Judgment
}

\author{
Victor Hugo Robles Francia \\ Universidad Juarez Autnoma De Tabasco, Villahermosa, Tabasco, Mexico \\ Email: vicrob13@yahoo.com.mx
}

How to cite this paper: Francia, V. H. R. (2018). The Affective Moral Judgment. Open Journal of Philosophy, 8, 225-242. https://doi.org/10.4236/ojpp.2018.83017

Received: February 10, 2018

Accepted: May 19, 2018

Published: May 22, 2018

Copyright (C) 2018 by author and Scientific Research Publishing Inc. This work is licensed under the Creative Commons Attribution International License (CC BY 4.0).

http://creativecommons.org/licenses/by/4.0/

\begin{abstract}
The affective though and the intuition in moral judgment has been discovered lately (Haidt, 2001). This article analyzes the Moral Judgment theory (Kohlberg, 1964) and the basic logical operations (Piaget, 1950). The rational stages with a few intervention of emotion have been historically assumed by moral judgment theory, which judges the affective as a mistaken notion and as a simple cognitive extension (Greene \& Haidt, 2002). This paper demonstrates that the Piagetian basic operations, seriation and categorization are applicable to an affective system. In addition, the intuition is a moral determinant and finally, that neuronal activity confirms an intuitional cognition for the resolution of social problems. It is expected that the present deliberation guides and stimuli researches on the intuition and emotion in moral judgment.
\end{abstract}

\section{Keywords}

Moral Judgment, Intuitionist Cognitivism, Moral Emotions

\section{Introduction}

The eternal struggle between the reason for controlling passion, the instinct against the moral conscience, is exalted when an incredibly bad or good action is evident. Since ancient times, it has been allegorically written between the divine reason and the animal instinct. The Plato's Phaedrus dialogue tells that the soul descends to a mortal creature (Martino, 2014). In the ancient myth, the human charioteer's job was to guide a pair of winged horses: one white, noble and good, personalized by the rationality; the other horse, black and ignoble, symbolized the passions. A virtuous driving towards the intelligible, the goodness and the perfection, the ideas world is not perceptible by senses; avoiding the badness and the ignorant, the material and sensible world (Burt, 1889). Gilson (1981) thinks that such archaic perspective, through the medieval vision, has been denigrated to the affective thought, due to its implication with passion and sin. Emotions 
are considered as materialistic and despicable conceptual errors.

Amorim Arantes De Araújo and Sastre Vilarras (2003) say that the rationality is not usually successful in shaping the moral character; the affective must be recognized in resolving conflicts that implicating individual and collective aims, this means that the affective moral judgment is more successful than the pure rational. Greene and Haidt (2002) has been discovered through theoretical considerations and through evidence based on neurosciences that emotions and the rational process are both important even with a predominance of the automatic emotional process (Greene \& Haidt, 2002).

Greene and Haidt (2002), Haidt (2001), Vélez García and Ostrosky-Solís (2006), Amorim Arantes De Araújo and Sastre Vilarras (2003), Rest, Narvaez, Thoma and Bebeau (2000) advise that the moral psychology of a whole era, the fifties and sixties, and some subsequent decades, has been dominated by the Kohlberg's moral judgment theory. This theory assumes Piaget's principles shown in infants and adolescents (Erdynast, Chen, \& Ikin, 2016); it recognizes some empty spaces in the psychological trends of moral judgment, where, cognitivism has tried to find the combination of intellectual styles and interpersonal experiences, as well as verbal and logical processes, which move people to deduce a moral law (Vélez García \& Ostrosky-Solís, 2006) and at the same time, as a paradigm against emotive irrational assumptions (Haidt, 2001).

\section{Methodology}

Several academic searches were made to locate the bibliographic documents. A bibliographic search was carried out in August of 2017 in EBSCO using the key words: Moral Judgment, Affective Moral Reasoning, Kohlberg and Piaget. Another search was executed in the "Google Scholar" with the same terms.

Documents were selected by their contributions as critical revisions to the fundamental theory of Kohlberg's moral judgment, the weak aspects of this theory. Also, they were selected as Piaget's background, his forgotten precepts. In addition, Kohlberg and Piaget primary sources were chosen; as well as related current references, and as complementary affective principles on moral reasoning, the intuitionist cognitivism and electroencephalography studies, empirical studies on neuronal activity were identified that show the affective use in moral judgment. In this way, the theoretical contributions provided by Kohlberg are criticized, the current explanatory limitations of his theory on the moral performance of the person and their complementarity from the affective are described.

This paper observes the following research structure 1) the main theoretical framework of moral judgment (Kohlberg, 1964, 1968, 1976), 2) the predominance of the conventional assumption of logical precepts of Piaget (1950, 1951), and 3) the demonstration of the affective moral judgment.

The demonstration of the affective moral judgment was done by applying logical operations to the affective system (Piaget, 1950, 1951); the intuitive cognitive concept (Greene, Nystrom, Engell, Darley, \& Cohen, 2004; Amorim Arantes De Araújo, V and Sastre Vilarras, 2003; Greene and Haidt, 2002; Dedeke, 2015), the 
instinctive reactions (James, 1989) and the evidence of neuronal activity of moral emotion (Greene, Nystrom, Engell, Darley, \& Cohen, 2004; Greene \& Haidt, 2002).

\section{The Kohlberg Moral Judgment Theory}

Forsha (2017) establishes that Kohlberg proposed a deontology and supported a moral education. The Kohlberg's researches, verified in different cultures and ages, show universal patterns in the development moral judgment stages (Kohlberg, 1964, 1968, 1976). This theory is seen from a constructivist perspective of morality, which analyzes moral conflicts as dilemmas of justice (Amorim Arantes De Araújo \& Sastre Vilarras, 2003). Also, Kohlberg's theory of moral development $(1964,1968,1976)$ establishes that education is based on the development of the rational capacity of justice. Similarly, Greene and Haidt (2002) state that moral judgment has historically been assumed as the result of a rational process established by Kohlberg and Piaget, with little or null attention on the moral emotions, identifying the origins of human morality as a simple extension of the cognitive process.

The Kohlbergian precepts have driven several studies. For example, Rest's investigations, the design of his questionnaires (Rest \& Narvaez, 1998) which have collected data for over 25 years, getting a great amount of samples $(50,000)$ as well as reinterpretations on the cognitive criteria themselves (Rest, Narvaez, Thomas, \& Bebeau, 2000). Likewise, the Kohlbergian theory has supported Lind's studies $(1982,2002,2004,2008)$ on the moral judgment as a competence, the design of his questionnaire, the method of discussing dilemmas, based on the person's cognition, because his theory has also served as a basis for his research on the increase of moral judgment competence in populations as Thailand, Germany, and other countries, by focusing on the individual logical discourse competence (Lind, 2009, 2011). Lind's investigations (2011, 2009), Rest, Narvaez, Thoma and Bebeau (2000); in Spanish from Pérez (1997), Barba (2002), Barba and Romo (2005) and Robles (2010), are a sample of the application of the model of Kohlberg's six moral reasonings (1964).

\subsection{The Moral Stages}

Kohlberg (1992) considers in his theory of moral judgment, constructivism, and the logical order, the taking of the social role and the morality of justice in the search of the reciprocal equilibrium between egos. Thus, a structure is entirely constituted in a cognitive stage of moral judgment, which is hierarchically distributed according to the ages of the human being (Pérez, 1997).

Kohlberg $(1964,1968)$ states that a cognitive stage is a system with an invariant sequence and qualitatively differentiated, through which the human being resolves moral conflicts. Kohlberg and Wasserman (1980) say that the stages are cognitive developments because their frontiers make qualitative changes, self-conscious, interpersonal relationships, and above all, judgment about right and wrong. Cognitive development considers as a basis, the stimulation of the 
child's active thinking for his moral education, developing it through the ascent through the stages (Kohlberg \& Wasserman, 1980).

Kohlberg $(1964,1968)$ establishes an invariable sequence of six stages in three moral levels of reciprocal justice and equilibrium. Stages one and two form the preconventional moral level. The stage one has a heteronomous reasoning of morality subordinated by the objects; this stage takes a naive vision of a moral meaning from objects rather than people. The bad action implies a punishment, while the correct one a prize. Thus, the authority establishes the bad or the right, not through the cooperation between equals. The stage two has an instrumental individualist morality of relative justice with the authority. In the second stage, individual consciously recognizes the specific interest of another person relative to his own, thus explaining the demand for justice. Here, an individual selfish utilitarianism is sought in order to get the greatest satisfaction with the least consequence of grievances.

Kohlberg $(1964,1968)$ founds the second moral level. Stages number three and four constitute this conventional level. Stage three possesses a conscious reasoning of an interpersonal morality, recognizing the interests of a third individual or group. Here, the person seeks the approval of the others. Following the golden rule, imagining himself into the role of another. The fourth stage has a morality of the social system, where the person assumes himself as a social member, identifying its symbols and its impartial arrangements for all its members. At this stage, the important is to maintain the system, the institutions and fulfill the social roles.

Kohlberg $(1964,1968)$ expresses that the third is the highest moral level; stages five and six constitute this postconventional level. The stage five has a reasoning of common good, of human rights, preserving all members of a society and even minorities. Developing a society instead of keeping it, this postconventional level finishes with the moral stage number six, the last one. It has a deontological morality, a free conscience where the universal imperatives are above the social rules, justifying occasionally the breach of some social rule.

\subsection{Cognitive Development}

Kohlberg (1964) affirms that the child after learning to speak develops three stages of reasoning: the intuitive, the operational concrete, and the formal operational. Around the age of seven years, children are placed in the stage of concrete logical thinking, by making logical inferences, classifying things and making quantitative relationships about concrete things. Then, many adolescents are located in the formal operations stage, because of abstract reasoning. The last one is formal operational thinking, which considers all combinations, the relationships between elements in a system, formulating hypotheses, deducing them and verifying them with reality. Kohlberg (1976) sustains that generally adolescents and adults continue entirely in the stage of concrete operations, many remain in the stage of partial formal operations, and most of them are in the highest stage 
of formal operations.

Kohlberg (1968) determines that an advanced logical reasoning determines the moral level proportionally, if logical thought is high then the moral reflection is equally high, thus it gives a "parallel" existence between logic and morality. Its application is carried out in the moral stages, arguing that a person with a concrete operational logic stage will be limited to a preconventional reasoning, avoiding punishment and putting the self-interest first than the authority interest. Kohlberg (1976) points out that growth towards a formal logic is a necessary condition for moral development, then many persons have a higher logical thinking rather than their own moral stage. Moral reasoning depends on logical growth, Rest, Turiel, and Kohlberg (1969) found that superior moral reasoning modes higher to their own were preferred by infants. Kohlberg $(1968,1976)$ concludes that logical development is a necessary condition for moral development.

According to Vélez García and Ostrosky-Solís (2006) and Langford (1995) verbal and logical processes are privatively attributed to the people's capability to infer a moral law. Kohlberg's cognitive development comes out because of the interaction between a child and his environment. Kohlberg (1968) recognizes that the main foundations of cognitive development are:

1) The cognition refers to adaptive actions of objects or internalization of such actions; the balance between action and object which is what sets the maturity of cognition.

2) Cognition through the stages of structural reorganization, cognitive structures are radically differentiated from a stage to another.

3) The implication of structural reorganization is the source of cognitive structure and cognitive development, and it is found in the interaction between organism and environment.

4) The optimal conditions suggest some optimal balance of discrepancy and correspondence between the behavior structures and the structure of their psychological environment.

5) From birth, there are inherent reasons for the cognitive activities, but these reasons also suffer from a structural change in the development.

6) The cognitive and the affective are functions, without psychic content nor structures; they are parallel aspects of structural transformations of the development.

\subsection{The Social Role}

Once that logic has been developed by the children, Kohlberg $(1964,1968,1976)$ says that the stages of social roles are developed, in which the person observes the actions of others, interpret their thoughts and their feelings and takes conscience of his position in society. The social stages are closely related to moral thought, but they are more general because they cover broader concepts than those only related to justice and rightness (Kohlberg, 1964, 1968, 1976). A social stage requires the corresponding development of moral judgment, by giving a 
vertical sequence of moral levels and the corresponding horizontal social role. Thus, a formal logical stage allows a person to abstract the elements of a social system, for assuming roles and establishing himself in a moral stage. We can see that only the formal logical thinking, according to Kohlberg, is the basis of moral reasoning (Kohlberg, 1964, 1968, 1976).

Kohlberg $(1968,1976)$ found out based on Piaget's work frame $(1950,1957)$, that new roles improved moral reasoning and promoted moral judgment. Kohlberg $(1964,1968)$ assumes a formal logical perspective as a moral reasoning principle and with this principle, he admits the assumption of social roles. The structure of justice is the essence of morality, Kohlberg (1976) declares that the interests in situational diversity come into conflict, demanding the justice thought in order to distribute what corresponds to each actor, as well as a balance on the mobility of relationships and social actions. Similarly, Lind (2009) and Schillinger (2006) determine that the perspective of the environment and the social roles are fundamental axioms in moral judgment theory.

Kohlberg (1976) considers that there are four moral perspectives in decisional strategies. The first strategy, the normative order is guided by the rules and social roles, which affect the decisional vision of the elements of rules. The second, the utilitarian consequences, determines a decision based on the good or bad consequences for himself and/or others caused by an action in a particular situation. The third, justice or equity, guides the decision of freedom, equality, and reciprocity between persons. The fourth, of the ideal self, is decided by pretending an actor's good self-image, or as someone with virtues, and independent of the consent of others (Kohlberg, 1976).

\section{The Piaget's Theory}

\subsection{Piagetian Stages}

Marwaha, Goswamim and Vashist (2017) relate the cognitive stages to the infants' logical thought, to the IQ. Before Piaget $(1950,1951)$ refuted the hereditary transmission of rational thought in the children, because it constituted a very weak hypothesis, the cognitive stages constitute its origin. Piaget (2009) warns that the emergence of causality through three possibilities: 1) The external experience that comes from associations imposed by the things themselves; 2) The feeling of internal experience derived from personal activity; 3). The relational perception of things, or between things and the person, producing a deductive result (Piaget, 2009).

Through the different kinds of experience, the different stages are developed with distinct reflective modes about any problems at different ages of children. These thinking modes form an invariant sequence in individual development where cultural factors could activate them, decrease them, or stop them, but without changing the sequence (Piaget, 1960).

Each stage is a sequential thought mode that forms a "structured whole". A given response-stage about a what task does not only to represent a specific de- 
termined response by getting the knowledge and being familiar with that task or with similar ones; it represents more a fundamental organization of thinking. Stages are hierarchical integrations, which form a differentiated order of increment and they are integrated structures to complete a common function where the organism establishes a balance between assimilation and accommodation, the higher stages reintegrate the structures found in the lower stages (Piaget, 1960).

Piaget $(1971,1991)$ finds that each stage has an original structure, whose essence subsists as a substructure of the new stage formed, evolving for a better balance. Every act thought or feeling is the reaction to a need. The person acts, visibly or internally, driven by a "mobile", always translated into a need, understanding this one as the manifestation of an imbalance; behavior is rearranged whenever something modifies the equilibrium (Piaget, 1991). Finding an external object excites a need due to the fact that it comes into conflict with some of the mental tendencies, thus stimulating the acting. Contrarily, when the need is satisfied, the affective and intellectual balance is reestablished when facing a new stimulus, and the previous mental organization (Piaget, 1991).

\subsection{Justice Morality}

Piaget $(1966,1971)$ proposed a unified representation of cognitive development, by covering an extensive set of precepts and skills, which the human being, from childhood to adolescence, uses to solve problems (Siegler, 2016). Lourenço (2016) emphasizes the interpretation of the developmental stages of the Piaget's theory, particularly the meaning of development in his theory, as a process of equilibrium (Piaget, 1957) that is coordinated within a coherent whole (Lourenço, 2016).

Piaget's theory $(1957,1971)$ predominantly recognizes a morality of reciprocity, the acquisition of autonomous moral consciousness and the rational environment as the cause of logical thinking on the precepts of children development (Piaget, 1952, 1976). In society the rules of reciprocity, where there is a moral of the autonomous conscience forces individuals to take a relative position with respect of others without eliminating the individual perspectives (Piaget, 1952, 1957).

Piaget (1991) declares that the concepts and relationships constitute a system whose elements are supported and balanced with each other, causing the transition from the intuitive reflection to a logical thought, from a perceptual scheme of internalized representations to a mental structure of a higher order capable of carrying out generalizable, reversible and, combinable logical operations (Piaget, 1991). This structure is typical of the highest mental process which provides a higher equilibrium, rather than the intuitive one because the acquired reversibility transforms the existence of a balance between the assimilation of things to the spirit and the accommodation of the spirit in front of the things. The spirit frees itself from the immediate selfishness reaching a social coherent state, cooperation, a subordinated spirit to the laws of reciprocity (Piaget, 1952). 


\subsection{The Logic Operations of Piaget}

The infant gets to logical principles by his living rational environment, the progress towards high stages is especially facilitated by the continuing influence of the adult's perspective (Piaget, 1962, 2009; Haan, Langer, \& Kohlberg, 1976). In the coherent whole, reciprocity in the distributive justice is a central axiom in Piaget's cognitive development theory (1957), and a balance of the system elements based on basic operations. Piaget $(1957,1991)$ establishes an initial operation where reversible structures are organized present their laws of totality. Reversibility is carried out when each term is conceived simultaneously smaller than the following and larger than all the preceding, this allows the thought to find its method of construction and interleaving, after forming a series, elements from another system (Piaget, 1991).

Reversibility is the initial operation of cognitive thinking. Piaget $(1967,1991)$ founds the essential system of logical operations forming "classes", consisting in this way, of any classification, as a whole, and its parts. We deduce from this author, the placement of the elements in the whole or, its inverse operation, the whole in relation to the placement of its elements. Ensuring that, the reversibility of thinking about the system is higher and later than the intuitive system. Piaget $(1970,1991)$ affirmed that logical operations arise from the abstraction of the actions, not from the objects: fixing and focusing on the eye, the sense of sight, hearing orientation, reconstruction with hands, in order to recognize by touch, inhaling deeper smells to distinguish by smell and tasting something in the mouth to recognize by taste, originate abstraction and logical operations (Piaget, 1951).

Piaget $(1970,1991)$ says, regarding classification, that a class exists exclusively because it concurs in an inclusive relationship with the general system because the whole is constructed by hierarchical assemblies that make up a classification. On the other hand, regarding seriation, this is consistent with the ordering actions of objects. Resulting that thought becomes logical by organizing operations systems that obey a common law set: 1) Composition, a third operation is the result of a possible arrangement of two operations of a set (Example: $+1+2=$ +3$.$) ; 2) Reversibility, there is an inverted operation for every operation (Exam-$ ple: +3 its inverse is -3$)$; 3) Invalidation or identity, and the result between direct and inverse operations provide an identical or null operation (Examples: +2 $-2=0$ ) operation; iv. All associations can occur between operations (Example: $+1+2=+3-3=0$ ) (Piaget, 1970, 1991).

The common procedures set, the logical operations (reversibility, classification, and seriation), the interaction with the object and the constant search for equilibrium, form the assumptions by which Kohlberg (1976) formulates his evolutive-cognitive theory of six moral stages. Such assumptions are examined below to demonstrate such logical operations, intuition, and brain activity; all of them are employed in the affective and constitute the evidence on its function on moral judgment. 


\section{The affective Moral Judgment}

\subsection{The Emotional Response}

Kohlberg and Hersh (1977) recognize that the moral judgment theory was not sufficient for moral action, other factors, such as the telos, the character and the impetus of the ego, influence it. They asserted that the imperatives of human morality would not be found in any theory because it would be insufficient for moral education. Thus, Kohlberg's theory has implied an important criticism, its inconsistency with the living reality of people. Amorim Arantes De Araújo and Sastre Vilarras (2003) point out the lack of consideration of inseparable elements of everyday moral conflicts, the social axiological representation and the affective needs of the individuals.

Haidt (2001) expresses great disbelief about moral reasoning, due to the rejection of intuition, the "a posteriori" construction and above all, because the change of the moral action is caused more by the affective than the cognitive reflex (Haidt, 2001). Kohlberg's theory about moral development require that the affective aspects of the human thought do not interact evidently in the cognition of moral judgment (Greene \& Haidt, 2002), meanwhile in Piaget's discourse (1984) is not in such way. Piaget (1984) shows that the moral is a set of control rules that the affective existence uses to direct itself. The elementary feelings of the child do not tend to be regulated from the inside, on the contrary, the external individuals are the ones who restrict their emotions. Piaget (1984) also assumed there were only two kinds of actions, logical and affective, and that the child seemed to quickly acquire a basic moral structure about good and bad (Piaget, 1984).

Regarding the distributive inequality, LoBue, Nishida, Cynthia, DeLoache, and Haidt (2011) show evidence that the emotional response on the equity arises at a very young age in children, from three to five years old, before the verbal argumentation capacity. In the case of receiving a minor gift, dislike or anger over the equitable distribution forms a brick in the human moral building (LoBue, Nishida, Cynthia, DeLoache, \& Haidt, 2011).

\subsection{The Logical Operations Applied to the Affective}

Piaget $(1984,1991,2009)$ recognizes that both affective and cognitive elements influence thought. In addition to the social dimension, this author proposes six different development stages in the child. From the first reflex stage, of the nascent emotions and instincts; the second, the first motor habits, differentiated perceptions and feelings; the third, the motor-sensorial intelligence; the fourth, an intuitive intelligence and submission to the adult; the fifth, where logic begins with concrete intellectual operations on the moral and social feelings of cooperation; and the sixth, in adolescence, the abstraction of intellectual operations (Piaget, 1991).

The characteristics of Piaget's theory (1984) have been applied to the theory of moral judgment. However, Kose and Arslan (2015) examine shaping stages and 
sequences of the Piagetian theory, they reconsider errors in its interpretation. Thus, regarding reciprocal morality, Piaget (1984) emphasizes the involvement of the affective through logical operations.

It is demonstrated that the classification and reversibility are also executed in an affective system. Piaget (1991) declares that a family affection system is only understood in terms of a totality of relationships: great-grandfather, grandfather, father, son, grandchild, great-grandchild. Here, the relationship and the age order are established: the age of the grandfather is greater than the father and less than the great-grandfather. Likewise, a system is established in affective interactions, for example, great-grandfather "love" grandfather "loves "father "loves" son "loves" grandson "loves" great-grandson. The reversibility is applicable in the "love" feeling and its consequent, "is loved by". It follows that the father is loved by his grandfather and he loves his son. Similarly, to the concept of respect, the one who respects respected individuals will be enough so that the last one can issue a mandate that becomes an obligation, the duty originates from the one who has the feeling of respect. The heteronomous obedience is the first moral rule of the child and the will of the parents constitutes his first criterion of good, long before understanding the moral rule by itself (Piaget, 1984). The great-grandfather has greater respect than the grandfather, or than the father, the son and the grandson, in order to express a similar relationship to "greater than". The son who respects the father is not intelligible anymore with the whole system of the feeling of respect for kinship. Also in the reversibility, the father respects the grandfather and he is respected by the child, and this is an example of the application of such law.

The actions also have affective purposes, returning to what was established by Piaget (1991), the logical operations are born from the abstraction of the facts that affect the emotional state of the person. The facts stimulate a feeling and attention to the senses. Applying the abstraction logical laws on the affective, we have i. Composition. In the example: $\boldsymbol{\text { man }}$ woman $=$ manwoman, the love between a man and a woman is the result of a man loving the woman and the woman loving the man. The same happens with the feeling of respect. ii. Reversibility. For each emotion, there is an inverted emotion, a positive feeling against a negative feeling, love against hate. iii. Nullity or identity. An emotional excitement either pleasant or positive is suppressed by an unpleasant or negative emotional stimulation and may be perceived as an emotional balance, the direction, and magnitude of a feeling equidistant with the magnitude and the opposite direction to another. iv. All associations among these logical operations can be made. For example, the result of love between men and women against the reversibility of hatred between men and women establishes the affective nullity. Thus, the logical laws, composition, reversibility, nullity, the association among them, the seriation and classification occur in the affective.

\subsection{The Intuitionist Cognitivism}

Greene, Nystrom, Engell, Darley and Cohen (2004), Amorim Arantes De Araújo 
and Sastre Vilarras (2003), Vélez García \& Ostrosky-Solís (2006), Greene and Haidt (2002) and Dedeke (2015) among others, recognize a paradigm shift from the unconscious automaticity of mind to solve complex social problems, giving more importance to the feelings and intuition in moral judgment. Resuming Piaget's (1984) forgotten paradigm, which establishes that the first intuitive and spontaneous valuations of the infant are the main achievements of the initial emotional life of the human development. Intuition is the beginning of the nascent moral feelings (Piaget, 1984).

Dedeke (2015) argues that the intuitionistic-cognitive model is an opportunity to provide a theoretical approach from the neuroscience. Greene and Haidt (2002) declare that the affective perspective in moral judgment is very similar to the aesthetic judgment, where an action is seen or an experience is evoked, this generates an instant feeling of approval or disapproval. Such feelings do not cross through stages of consciousness or inferences to reach a conclusion, however, a valuing intuitive and affective feeling appears suddenly produced by the social environment (Greene \& Haidt, 2002).

The intuitionistic cognitivism emphasizes the role of intuitive and emotional decision-making processes. The moral valuations are generated quickly and automatically, without deliberation or deductive reasoning; the moral relevant estimations are self-evident truths that are not deductible nor inducible (Vélez García \& Ostrosky-Solís, 2006). Greene and Haidt (2002) argue that people instantly use moral stereotypes about other individuals. People feel stimulated suddenly to defend themselves against the threats of the others; by consensus, people want to influence their social relationships, in order to induce an inferential process in order to explain their moral decisions.

Haidt (2001), Iyer et al. (2012) emphasize moral judgment as a sudden unconscious determination that induces a posteriori reasoning. Here, intuition and affective reactions are cognition forms. These authors clarify that the intuition is quick, simple and instant, where the result, but not the process is accessible to consciousness, while the reasoning is slow, requiring effort and some procedure that be understandable to consciousness.

\subsection{From the Instinctive Reaction to the Moral Emotion}

In the twentieth century, according to Mandler (1990), a paradigmatic shift had taken place from William James, who founded the theory on the emotional experience and specified it as an indirect excited feeling. The axiom that contradicted what was established by Wundt (1979) mentions that a feeling was not an understandable process related to an emotion (Mandler, 1990), from an atomistic perspective, says that the phenomena were seen as the succession of ideas which derived from central precepts, the affective as an extension of the cognitive.

James introduced the first constructivist psychology of emotion, by studying the generating behavior processes and conscious experiences (Mandler, 1990). 
James (1989) established the unconscious instinctive automaticity, in which moral judgment was similar to the aesthetic one in their emotional setting and the sudden emotional valuation. According to Mandler (1990), the theoretical explanations of James, the persistent research on the emotional pattern and the cognitive discovery on visceral theoretical explanations on emotion, are still current.

James (1989) established the instinctive unconscious automaticity of the moral valuation, which generates a sudden emotion. James (1989) said that the aesthetics emotion, flat and without attachments, the living pleasure of certain lines and masses, as the combination of colors and sounds, is a complete sensitive experience. A primary optic, audible; even olfactory, gustatory and tactile, feeling, which is not dependent of repercussions of other feelings aroused elsewhere (James, 1989). In moral judgment happens similarly, its pleasurable or painful assessment is originated by primary sensorial responses, which characterizes a pure sensation (James, 1989).

\subsection{Neuronal Activity of Moral Emotion}

James (1989) exposed that the cerebral cortex has parts that can be stimulated by reactions in each organ sense and in each abdominal viscera, achieving in this way a representation of emotions. Something impacts on a sense organ, affecting a cortical portion, excited internally, the reflex currents pass through their preorganized channels, altering the condition of the muscle, the portion of the organ and the respective viscera, and that perception, in the cortex is combined in the consciousness and becomes a heartfelt emotional thing, without invoking new principles or postulates, only the reflex circuits (James, 1989).

James (1989) says that emotional excitations reside contiguously with the instincts. Things that cause some external activity, such as anger or fear also produce distinctive features and visible alterations, such as gestures in the face, changes in breathing or blood flow. Although the external events are blocked, emotional residual signs are revealed, a scarcely noticeable interlace between instinctive responses and emotional signals, for any object that causes a reaction of an instinct, and also stimulates an emotion (James, 1989).

According to James (1989), emotions are instincts, the body ends his emotional response in himself, while his instinct reacts experiencing a practical relationship with the exciting thing. The evocation of the object is enough to trigger arousal from both instincts and emotions. The moral emotional mental stage is born when the person values his actions as good or bad, a single body shake is articulated just by thinking about the stimulus and the cognition of its quality (James, 1989).

James (1989) indicated that the moral emotion is a primary sensorial experience, an immediate sensation that does not base its experience on any other effect. The moral stimulation excite feelings caused by the transmission of reflexes, this causes secondary signs such as: haltingly, sobbing chest, dilation of the nostrils, sudden increase in the heart beats, among other possible shown symp- 
toms of morality (James, 1989).

According to James (1989), the relived sights and sounds can be ideal, but different, the relived emotion might be distant, but it is real and it moves faster than any other feeling. Also, a prompt trial in mind and a specific action will be produced together many times when the stimulus is present, which in turn will generate a decrease in the reaction of some organ of the body (James, 1989).

Regarding the neuronal activity stipulated by James (1989), alterations in the cerebral cortex are due to an object felt emotionally, Greene, Nystrom, Engell, Darley and Cohen (2004), Greene and Haidt (2002) have shown neuroimaging evidence. They have discovered a greater socio-emotional processing of the deontological intuition; the moral perspective is not based psychologically on practical rational imperatives, but in emotional reactions which are rationalized a posteriori and are significant to the moral valuating.

Greene and Haidt (2002) support that emotion is an important motor force in the moral judgment, the moral emotions activate the amygdala, thalamus, midbrain superior; Vélez García and Ostrosky-Solís (2006) add the insula and the encephalon. Englander, Haidt, and Morris (2012) show correlations between moral emotional stimuli content and some regions of the brain: The anterior and posterior cingulate gyrus, the precuneus, the bilateral temporoparietal junction, the superior frontal gyrus, the inferior frontal gyrus, the angular gyrus and bilateral parietal operculum areas.

\section{Conclusion}

It has been shown that suppression of the affective by the Kohlbergian cognitivist perspective on the moral judgment does not explain the emotional automatic reflexes or the flexible uses of moral phases (Krebs \& Denton, 2005) which has been a mistake. The common operations of Piaget (1991), about the equilibrium of justice, recognize the affective actions. The system, the full social whole, the set of individuals restricts the emotions (Piaget, 1984). In this sense, it was shown that the Piagetian logical operations, seriation, classification, composition, reversibility, nullity, and association are applicable in an affective system. In this intuitionist social paradigmatic review, I can conclude as Dedeke (2015), that the importance of moral feelings and the intuition must be recognized. My deduction was supported by Iyer et al. (2012), Greene and Haidt (2002), Haidt (2001, 2008) and the Piaget $(1950,1952)$ theory revisited, it determines that a moral decision arises suddenly in an unconscious way, and then, a rational deliberative processing is done.

On the other hand, researches on emotional patterns associated with the human decisions and the actions should be done in order to solve social problems in different cultures and global demarcations (Keltner \& Haidt, 2001). Besides, getting into deep studies on the degree into which emotions affect moral life (Greene \& Haidt, 2002), as well as integrating social emotions par excellence, shame, and pride, socially and culturally conditioned (Bericart, 2012), which can only be eliminated through indirect forms (Orsi, 2006). 
In addition, the present paper contributes to designing an applicable method of intervention supported now on the affective and the intuition. Solving thus the ineffective results of the pure cognitivist method found by Robles $(2011,2012)$, the low level of moral judgment in workers reported equally by Robles (2010, 2012) and low level of moral judgment of students reported by Barba (2002).

Future studies must focus on unconscious reaction in the moral judgment, the moral development depends of the sudden unconscious determination and cognitive development stages are strongly operative in the moral functionality, the moral judgment complexity implies an interrelated dynamic between unconscious intuition and logic cognition (Kaplan \& Tivnan, 2014). So, Bericart (2012) concludes that the defined moral emotion is the body experience and flows until the consciousness, with physiological and neurological reflexes that establish a reality felt emotionally to the person and to his group, and it establishes a posteriori, a cognitive phase of evaluation (Bericart, 2012).

In this scientific topic is imperative to assume wide theoretical frameworks, Psychology, Sociology, and Philosophy are disciplines that help to clarify related concepts. In the present article, similarly to Timon Herrero and Sastre Vilarrasa (2003), I determined that is very important to assume theoretical contexts that include individual and social visions. From the perspective of brain reactions, James (1989) stipulates that the moral emotional stimuli have a relationship with the moral judgment (Prinz, 2007). Here, Greene, Nystrom, Engell, Darley and Cohen (2004), Greene and Haidt (2002), have shown, by neuroimaging, an evidence on socio-emotional in the ethical intuition processing: the cingulate gyrus anterior and posterior, the precuneus, bilateral temporoparietal junction, among others (Englander, Haidt, \& Morris, 2012). However, following the basis of Vélez García \& Ostrosky-Solís (2006), I can conclude that the differential characteristics of affective brain circuits are missing because the amygdala, insula, thalamus, and brain, for example, also are excited by an emotional stimulation with or without moral weight.

\section{References}

Amorim Arantes De Araújo, V., \& Sastre Vilarras, G. (2003). Moralidad, sentimientos y educación. Educar, 31, 47-66. https://doi.org/10.5565/rev/educar.304

Barba, B. (2002). Influencia de la edad y de la escolaridad en el desarrollo del juicio moral. REDIE. Revista Electrónica de Investigación Educativa, 4, 22-45.

Barba, B., \& Romo, J. (2005). Desarrollo del Juicio Moral en la Educación Superior. Revista Mexicana de Investigación Educativa, 10, 67-92.

Bericart, E. (2012). Emociones. Sociopedia.isa, 1-13.

Burt., B. (1889). Plato-In A Brief History of Greek Philosophy. Boston, MA: Ginn \& Company.

Dedeke, A. (2015). A Cognitive-Intuitionist Model of Moral Judgment. Journal of Business Ethics, 126, 437-457. https://doi.org/10.1007/s10551-013-1965-y

Englander, Z., Haidt, J., \& Morris, J. P. (2012). Neural Basis of Moral Elevation Demonstrated through Inter-Subject Synchronization of Cortical Activity during Free-Viewing. 
Plos ONE, 7, e39384. https://doi.org/10.1371/journal.pone.0039384

Erdynast, A., Chen, W., \& Ikin, A. (2016). Criteria for Multidomain Research. Behavioral Development Bulletin Erdynast, 21, 74-87. https://doi.org/10.1037/bdb0000016

Forsha, S. (2017). Virtue and Moral Development, Changing Ethics Instruction in Business School Education. College Student Journal, 51, 429-443.

Gilson, É. (1981). El Espiritu de la Filosofia Medieval. Madrid: Ediciones RIALP.

Greene, J., \& Haidt, J. (2002). How (and Where) Does Moral Judgment Work? Trends in Cognitive Sciences, 6, 517-523. https://doi.org/10.1016/S1364-6613(02)02011-9

Greene, J., Nystrom, L., Engell, A., Darley, J., \& Cohen, J. (2004). The Neural Bases of Cognitive Conflict and Control in Moral Judgment. Neuron, 44, 389-400. https://doi.org/10.1016/j.neuron.2004.09.027

Haan, N., Langer, J., \& Kohlberg, L. (1976). Family Patterns of Moral Reasoning. Child Development, 47, 1204-1206. https://doi.org/10.2307/1128466

Haidt, J. (2001). The Emotional Dog and Its Rational Tail: A Social Intuitionist Approach to Moral Judgment. Psychological Review, 108, 814-834. https://doi.org/10.1037/0033-295X.108.4.814

Haidt, J. (2008). Morality. Perspectives on Psychological Science, 3, 65-72. https://doi.org/10.1111/j.1745-6916.2008.00063.x

Iyer, R., Koleva, S., Graham, J., Ditto, P., Haidt, J., \& Young, L. (2012). Understanding Libertarian Morality: The Psychological Dispositions of Self-Identified Libertarians. Plos ONE, 7, 1-23. https://doi.org/10.1371/journal.pone.0042366

James, W. (1989). Principios de psicología. Ciudad de México: Fondo de Cultura Económica.

Kaplan, U., \& Tivnan, T. (2014). Moral Motivation Based on Multiple Developmental Structures: An Exploration of Cognitive and Emotional Dynamics. Journal of Genetic Psychology, 175, 181-201. https://doi.org/10.1080/00221325.2013.838936

Keltner, D., \& Haidt, J. (2001). Social Functions of Emotions. In T. Mayne, \& G. Bonanno (Eds.), Emotions: Current Issues and Future Directions (pp. 192-213). New York: Guilford Press.

Kohlberg, L. (1964). Development of Moral Character and Moral Ideology. In M. L. Hoffman, L. W. Hoffman, M. L. Hoffman, \& L. W. Hoffman (Eds.), Review of Child Development Research (Vol. 1, pp. 381-431). New York, NY: Russel Sage Foundation.

Kohlberg, L. (1968). Early Education: A Cognitive-Developmental View. Child Development, 39, 1013-1062. https://doi.org/10.2307/1127272

Kohlberg, L. (1976). Moral Stages and Moralization: The Cognitive-Development Approach. In T. Lickona (Ed.), Moral Development and Behavior: Theory and Research and Social Issues (pp. 31-53). New York, NY: Holt, Rienhart, and Winston.

Kohlberg, L. (1992). Psicología del desarrollo moral. Asun Zubiaur Zárate (Trad.), Bilbao: Desclée de Brouwer.

Kohlberg, L., \& Hersh, R. (1977). Moral Development: A Review of the Theory. Theory into Practice, 16, 53-59. https://doi.org/10.1080/00405847709542675

Kohlberg, L., \& Wasserman, E. (1980). The Cognitive-Developmental Approach and the Practicing Counselor: An Opportunity for Counselors to Rethink Their Roles. The Personnel and Guidance Journal, 58, 559-567. https://doi.org/10.1002/j.2164-4918.1980.tb00450.x

Kose, U., \& Arslan, A. (2015). Realizing an Optimization Approach Inspired from Piaget's Theory on Cognitive Development. Brain: Broad Research in Artificial Intelli- 
gence \& Neuroscience, 6, 14-21.

Krebs, D., \& Denton, K. (2005). Toward a More Pragmatic Approach to Morality: A Critical Evaluation of Kohlberg's Model. Psychological Review, 112, 629-649. https://doi.org/10.1037/0033-295X.112.3.629

Langford, P. (1995). Approaches to the Development of Moral Reasoning. Hove, OK: LEA.

Lind, G. (1982). Experimental Questionnaires: A New Approach to Personality Research. In A. Kossakowski, \& K. Obuchowski (Eds.), Progress in the Psychology of Personality (pp. 132-144). Amsterdam: North-Holland.

Lind, G. (2002). Moral Dilemma Discussion Revisited-The Konstanz Method. Chicago IL: Presentado en el meeting de la Association for Moral Education (AME).

Lind, G. (2004). The Meaning and Measurement of Moral Judgment Competence Revisited-A Dual-Aspect Model. In D. Fasko, \& W. Willis (Eds.), Contemporary Philosophical and Psychological Perspectives on Moral Development and Education (pp. 185-220). Cresskill, NJ: Hampton Press.

Lind, G. (2008). The Moral Judgment Test. http://www.uni-konstanz.de/ag-moral/mut/mjt-certification.htm\#certified_versions

Lind, G. (2009). Favorable Learning Environments for Moral Development-A Multiple Intervention Study with 3.000 Students in a Higher Education Context.

Lind, G. (2011). Promoviendo las competencias morales y democráticas: Expresarse y escuchar a otros. Postconvencionales, 3, 26-41.

LoBue, V., Nishida, T., Cynthia, C., DeLoache, J., \& Haidt, J. (2011). When Getting Something Good Is Bad: Even Three-Year-Olds React to Inequality. Social Development, 20, 154-170. https://doi.org/10.1111/j.1467-9507.2009.00560.x

Lourenço, O. (2016). Developmental Stages, Piagetian Stages in Particular: A Critical Review. New Ideas in Psychology, 40, 123-137. https://doi.org/10.1016/j.newideapsych.2015.08.002

Mandler, G. (1990). William James and the Construction of Emotion. Psychological Science, 1, 179-180. https://doi.org/10.1111/j.1467-9280.1990.tb00193.x

Martino, G. (2014). Filosofía y exégesis en las Enéadas. Las alas del alma plotiniana en su lectura del Fedro platónico. Areté: Revista De Filosofía, 26, 77-108.

Marwaha, S., Goswami, M., \& Vashist, B. (2017). Prevalence of Principles of Piaget's Theory among 4-7-Year-Old Children and Their Correlation with Iq. Journal of Clinical \& Diagnostic Research, 11, 111-115. https://doi.org/10.7860/JCDR/2017/28435.10513

Orsi, R. (2006). Emociones morales y moralidad. Ideas y Valores, 55, 33-49.

Pérez, E. (1997). Cognición y afecto en el desarrollo moral. Valencia: PROMOLIBRO.

Piaget, J. (1950). Introduction à l'epistemologie genetique: La pensée mathématique [Introduction to Genetic Epistemology: Mathematical Thinking]. Paris: Presses Universitaires de France.

Piaget, J. (1951). The Origins of Intelligence in Children. New York, NY: International Universities Press (Original Work Published 1936).

Piaget, J. (1952). The Child's Conception of the World. London: Kegan Paul Trench Trubner (Original Work Published 1926).

Piaget, J. (1957). Logique et equilibre [Logic and Equilibrium]. Paris: Presses Universitaires de France.

Piaget, J. (1960). The General Problem of the Psychobiological Development of the Child. 
In J. Tanner, \& B. Inhelder (Eds.), Discussions on Child Development (Vol. 4, pp. 3e27). London: Tavistock.

Piaget, J. (1962). Play, Dreams and Imitation in Childhood. New York, NY: Norton (Original Work Published 1945).

Piaget, J. (1966). The Psychology of Intelligence. Totowa, NJ: Littlefield, Adams (Original Work Published 1947).

Piaget, J. (1967). Logique et connaissance scientifique. Paris: Gallimard [Logic and Scientific Knowledge].

Piaget, J. (1970). Structuralism. New York, NY: Basic Books (Original Work Published 1968).

Piaget, J. (1971). The Theory of Stages in Cognitive Development. In D. Green, M. P. Ford, \& G. B. Flamer (Eds.), Measurement and Piaget (pp. 1-11). New York, NY: McGraw-Hill.

Piaget, J. (1976). The Grasp of Consciousness. Cambridge, MA: Harvard University Press (Original Work Published 1974).

Piaget, J. (1984). Los procesos de adaptación. Buenos Aires: Nueva Vision Argentina.

Piaget, J. (1991). Seis estudios de psicología (J. Marfa, Trad.). Barcelona: Editorial Labor.

Piaget, J. (2009). La causalité chez Tenfant (Children's Understanding of Causality). British Journal of Psychology, 100, 207-224. https://doi.org/10.1348/000712608X336059

Prinz, J. (2007). Can Moral Obligations Be Empirically Discovered? Midwest Studies in Philosophy, 31, 271-291. https://doi.org/10.1111/j.1475-4975.2007.00148.x

Rest, J., \& Narvaez, D. (1998). Defining Issues Test DIT-2 Versión 3.0. Minnesota: Universidad de Minnesota.

Rest, J., Narvaez, D., Thoma, S., \& Bebeau, M. (2000). A Neo-Kohlbergian Approach to Morality Research. Journal of Moral Education, 29, 381-395.

Rest, J., Turiel, E., \& Kohlberg, L. (1969). Level of Moral Development as a Determinant of Preference and Comprehension of Moral Judgments Made by Others. Journal of Personality, 37, 225-252. https://doi.org/10.1111/j.1467-6494.1969.tb01742.x

Robles, V. (2010). El papel del rol y el contexto en la competencia del juicio moral: Estudiantes de negocios vs. burócratas. Revista de la facultad de Ciencias Económicas de la Universidad Militar Nueva Granada, 18, 169-177.

Robles, V. (2011). La ineficacia de la discusión de dilemas morales en el crecimiento de la competencia moral en trabajadores y estudiantes. Dos casos mexicanos. Revista CES Psicología, 4, 47-59.

Robles, V. (2011). Perfeccionamiento de la deliberación moral en la orgnización. México: Plaza y Valdés Editores.

Robles, V. (2012). Complejidad De La Moralidad Organizacional: Una Discusión Sobre Diferentes Roles. Sotavento, 20, 106-117.

Schillinger, M. (2006). Learning Environment and Moral Development: How University Education Fosters Moral Judgment Competence in Brazil and Two German-Speaking Countries. Aachen: Shaker Verlag.

Siegler, R. (2016). Continuity and Change in the Field of Cognitive Development and in the Perspectives of One Cognitive Developmentalist. Child Development Perspectives, 10, 128-133. https://doi.org/10.1111/cdep.12173

Timon Herrero, M., \& Sastre Vilarrasa, G. (2003). Los sentimientos en el ámbito de la moral. Educação e Pesquisa, 29, 219-234.

https://doi.org/10.1590/S1517-97022003000200002 
Vélez García, A., \& Ostrosky-Solís, F. (2006). From Morality to Moral Emotions. International Journal of Psychology, 41, 348-354.

https://doi.org/10.1590/S1517-97022003000200002

Wundt, W. (1979). Wilhelm Wundt (1832-1920). Revista Latinoamericana de Psicología, 11, 170-172. 